\title{
Consumption of pomegranates improves synaptic function in a transgenic mice model of Alzheimer's disease
}

\author{
Nady Braidy 1,*, Musthafa Mohamed Essa2,3,*, Anne Poljak ${ }^{1,4}$, Subash Selvaraju 2,3 , \\ Samir Al-Adawi $\mathbf{i}^{2,4}$, Thamilarasan Manivasagm ${ }^{5}$, Arokiasamy Justin Thenmozhi ${ }^{5}$, \\ Lezanne Ooi $^{6}$, Perminder Sachdev ${ }^{1,7}$ and Gilles J. Guillemin ${ }^{8}$ \\ ${ }^{1}$ Centre for Healthy Brain Ageing, School of Psychiatry, Faculty of Medicine, University of New South Wales, Sydney, Australia \\ 2 Department of Food Science and Nutrition, College of Agricultural and Marine Sciences, Sultan Qaboos University, Al \\ Khoudh, Oman \\ ${ }^{3}$ Ageing and Dementia Research Group, Sultan Qaboos University, Al Khoudh, Oman \\ ${ }^{4}$ College of Medicine and Health Sciences, Sultan Qaboos University, Al Khoudh, Oman \\ ${ }^{5}$ Department of Biochemistry and Biotechnology, Annamalai University, Tamil Nadu, India \\ ${ }^{6}$ Illawarra Health and Medical Research Institute, University of Wollongong, NSW, Australia \\ ${ }^{7}$ Neuropsychiatric Institute, The Prince of Wales Hospital, Sydney, Australia \\ ${ }^{8}$ Neuroinflammation Group, MND and Neurodegenerative Diseases Research Centre, Macquarie University, NSW, Australia \\ * These authors have contributed equally to this work \\ Correspondence to: Gilles J. Guillemin, email: gilles.guillemin@mq.edu.au \\ Musthafa Mohamed Essa, email: drmdessa@gmail.com
}

Keywords: pomegranates; synapse; inflammation; amyloid beta protein; amyloid precursor protein; Gerotarget

Received: April 04, 2016

Accepted: June 17, 2016

Published: July 28, 2016

\section{ABSTRACT}

Alzheimer's Disease (AD) is a progressive neurodegenerative disorder characterized by extracellular plaques containing abnormal Amyloid Beta (AB) aggregates, intracellular neurofibrillary tangles containing hyperphosphorylated tau protein, microglia-dominated neuroinflammation, and impairments in synaptic plasticity underlying cognitive deficits. Therapeutic strategies for the treatment of AD are currently limited. In this study, we investigated the effects of dietary supplementation of $4 \%$ pomegranate extract to a standard chow diet on neuroinflammation, and synaptic plasticity in APPsw/Tg2576 mice brain. Treatment with a custom mixed diet (pellets) containing 4\% pomegranate for 15 months ameliorated the loss of synaptic structure proteins, namely PSD-95, Munc18-1, and SNAP25, synaptophysin, phosphorylation of Calcium/Calmodulin Dependent Protein Kinase IIa (p-CaMKIIa/ CaMKIIa), and phosphorylation of Cyclic AMP-Response Element Binding Protein (pCREB/CREB), inhibited neuroinflammatory activity, and enhanced autophagy, and activation of the phophoinositide-3-kinase-Akt-mammalian target of rapamycin signaling pathway. These neuroprotective effects were associated with reduced $\beta$-site cleavage of Amyloid Precursor Protein in APPsw/Tg2576 mice. Therefore, long-term supplementation with pomegranates can attenuate AD pathology by reducing inflammation, and altering APP-dependent processes.

\section{INTRODUCTION}

Alzheimer's Disease (AD) is a progressive neurodegenerative disorder characterized clinically by progressive cognitive and memory impairments [1].
Recent epidemiological studies have shown that at least 36.5 million individuals are affected by AD worldwide, with new AD diagnosis reported every 7 seconds [2]. Ageing represents the main risk factor for $\mathrm{AD}$ and its prevalence is expected to increase exponentially with age 
[1,3-5]. The aetiology and exact neuropathogenesis of AD remain unclear. However, AD is thought to be a complex multi-factorial disorder, and no effective therapeutic agent is available to slow down or prevent disease progression $[6,7]$.

The main pathological hallmarks of $\mathrm{AD}$ is the formation of extracellular Amyloid-Beta $(A \beta)$ deposits called senile plaques, and twisted intracellular neurofibrillary tangles containing hyperphosphorylated tau, a microtubular protein [8]. A $\beta$ plaques can induce synaptic loss in the neocortex and limbic system, leading to neuronal injury. $A \beta$ can also induce neuronal damage through activation of microglia, the resident immunoregulatory cells in the brain, leading to the production and release of neurotoxic and proinflammatory cytokines, such as Tumor Necrosis Factor (TNF)- $\alpha$, Interleukin (IL)-1 $\beta$, and highly volatile free radicals [9]. Microglial activation represents a critical process to facilitate the clearance of $A \beta$ from the brain via endocytosis $[10,11]$. Therefore, therapeutic strategies targeting neuroinflammation and microglial activation are highly desirable [12-15].

The generation of $A \beta$ is dependent on the proteolytic processing of Amyloid Precursor Protein [16] by $\alpha$-secretase, $\beta$-secretase (BACE1), and $\gamma$-secretase. $\alpha$-secretase is responsible for the cleavage of APP at the luminal region, thus preventing the formation of neurotoxic $\mathrm{A} \beta$ aggregates and plaques $[17,18]$. BACE1 is responsible for the cleavage of full length APP on the $\mathrm{N}$-terminus of $A \beta$, consequently leading to the formation of smaller soluble ectodomain fragment (sAPP- $\beta$ ), and a larger C-terminal fragment (C99) [19-22]. $\gamma$-secretase catalyses the formation of $\mathrm{A} \beta$ from the $\mathrm{C} 99$ fragment [23]. Given the significance of $A \beta$ in $A D$ pathology, therapeutic strategies aimed at interfering with the processing of APP are warranted.

Synaptic dysfunction represents another pathological presentation of AD. Synaptic plasticity is crucial for the maintenance of optimal memory and learning [24-26]. Since impairments in synaptic plasticity precede synaptic loss, changes to synaptic regulatory protein may represent an important biomarker for disease progression and cognitive impairments $[27,28]$. An important example is Mammalian Target Of Rapamycin (mTOR), a kinase associated with the maintenance of synaptic plasticity by modulating the anabolism of protein [29].

Pomegranates (Punica granatum Linn.) are composed of high concentrations of polyphenols compared to other fruits and vegetables [30-43]. Pomegranates have been extensively used for the treatment of several degenerative diseases in Unani, Ayurvedic and Chinese systems of medicine [44]. Dietary supplementation of pomegranate juice attenuated neurodegeneration in neonatal mice subjected to maternal hypoxic-ischemic brain injury $[45,46]$. We and others have previously shown that pomegranate supplementation with diet significantly reduced oxidative stress in brain [4749]. This effect of pomegranate was likely through inhibition of $A \beta$ accumulation, which in turn significantly attenuated oxidation of lipid and protein, restored Acetylcholinesterase (AChE) activity, maintained endogenous antioxidant capacity at near physiological levels in brain tissues of APPsw/Tg2576 mice, and improved spatial learning deficits [47-49].

The Tg2576 mice express APP KM670/671NL Swedish mutation, and demonstrates progressive agedependent behavioural deficits associated with increased A $\beta$ deposition. Moreover, this transgenic mice model exhibit decreased motor coordination, increased learning and memory deficits, and elevations in oxidative stress markers. Previous studies have identified significant memory impairment, and hippocampal neurodegeneration in Tg2576 mice. The current study explores the effect of pomegranate supplementation on stress in the brain, synaptic plasticity, neuroinflammation, and $A \beta$ production in the $\mathrm{AD}$ transgenic mice, and examines potential disease-related modifications to the expression of synaptic plasticity-related proteins, activation of the $\mathrm{PI} 3 \mathrm{~K} / \mathrm{Akt} / \mathrm{mTOR}$ pathway, neuroinflammation, and altered amyloidogenic processing.

\section{RESULTS}

\section{Long-term supplementation with $4 \%$ pomegranates improved synaptic structure protein in APPsw/Tg 2576}

Numerous studies have shown that the expression of synaptic structural protein is reduced in the brains of $\mathrm{AD}$ mice compared to wild-type controls [50,51]. We have shown that the protein expression of PSD-95, Munc181, SNAP25, synaptophysin, p-CaMKII $\alpha / \mathrm{CaMKII} \alpha$, and pCREB/CREB were significantly increased $(p<0.05)$ in the brain in APPsw/Tg 2576 receiving a diet supplemented with $4 \%$ pomegranates for 15 months than in APPsw/Tg 2576 mice receiving a standard chow diet (Figure 1).

We also assessed the mRNA expression of genes encoding for two important neurotrophic factors, BDNF and IGF-1 (Figure 2). Our data shows that both BDNF and IGF-1 are significantly increased in the brain by 15 months of treatment with a $4 \%$ pomegranate diet compared to APPsw/Tg 2576 mice receiving a standard chow diet.

\section{Long-term supplementation with $4 \%$ pomegranates reduces neuroinflammation in APPsw/Tg 2576}

It is well established that neuroinflammation plays a pivotal role in the pathogenesis of AD [12-15]. 


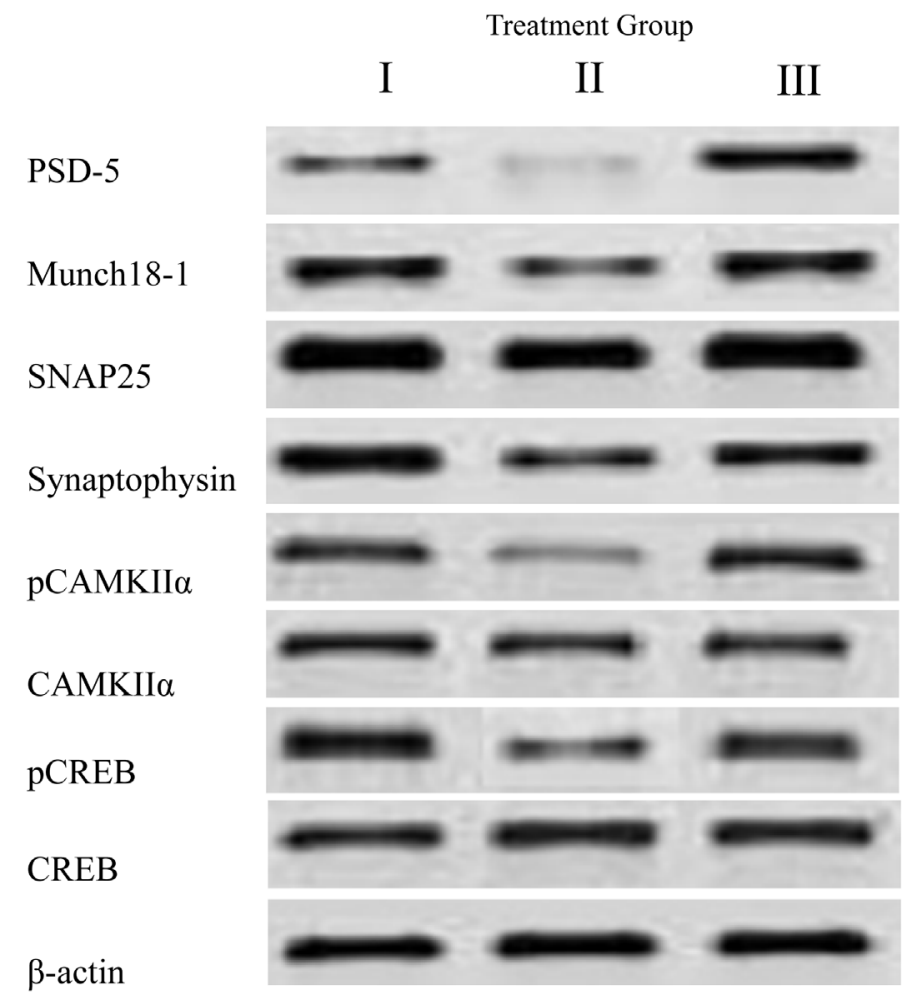

(B)
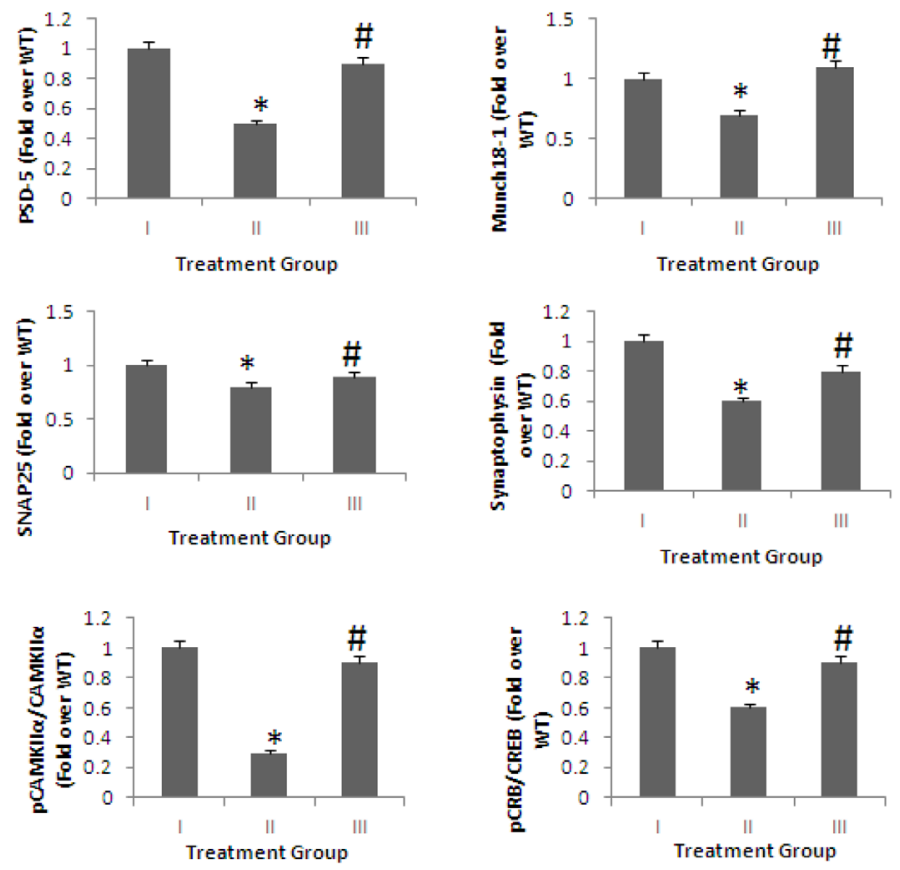

Figure 1: Synaptic structural proteins in brain homogenates detected by Western blot analysis. The levels of PSD-95, Munc18-1, SNAP25, synaptophysin, p-CaMKII $\alpha /$ CaMKII $\alpha$, and pCREB/CREB in the brains of mice fed $4 \%$ pomegranate diet for 15 months. Treatment I: Wild type (non-transgenic) control of the APPsw mice fed with regular diet; Treatment II: APPsw mice also fed with regular diet; and Treatment III: APPsw mice fed with $4 \%$ pomegranate fruit diet. A. The blot shown is representative tracings of an experiment done six times. B. Graphs are mean \pm S.E brains from tissue obtained from six rodents for each treatment group. Each bar of the quantification graph represents the corresponding band for each age group. Significance ${ }^{*} p<0.01$ compared to wild-type mice fed with regular diet, ${ }^{*} p<0.01$ compared to APPsw transgenic mice fed with regular diet. 
We examined whether long-term treatment with $4 \%$ pomegranates attenuated neuroinflammatory activity in APPsw/Tg 2576. To determine this, we quantified the expression of inflammatory genes in the brain. Our data shows that the expression of tnf- $\alpha$, il-1 $\beta, \mathrm{iNOS}, \operatorname{ccl} 2$, and il-10 were significantly decreased by diet supplemented with $4 \%$ pomegranates for 15 months $(p<0.05)$ (Figure 2).
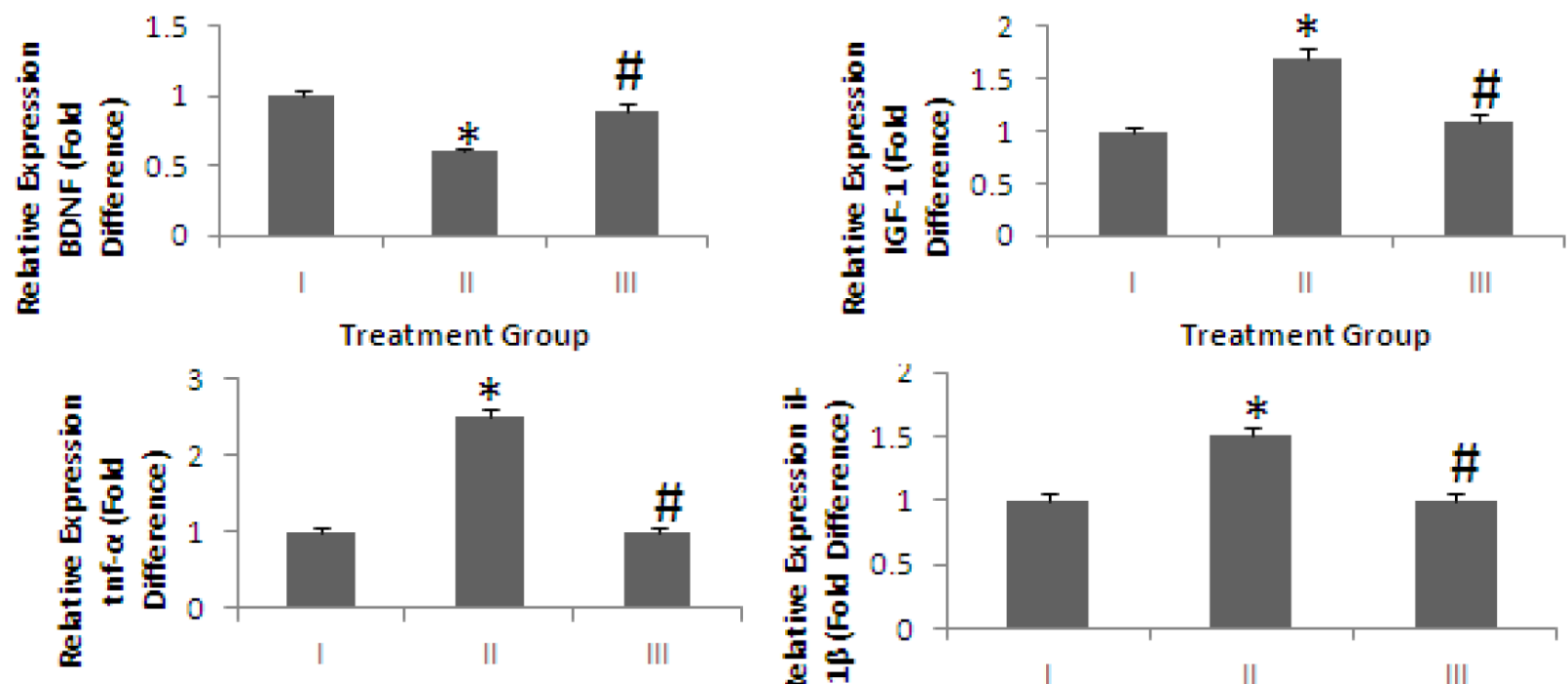

Treatment Group
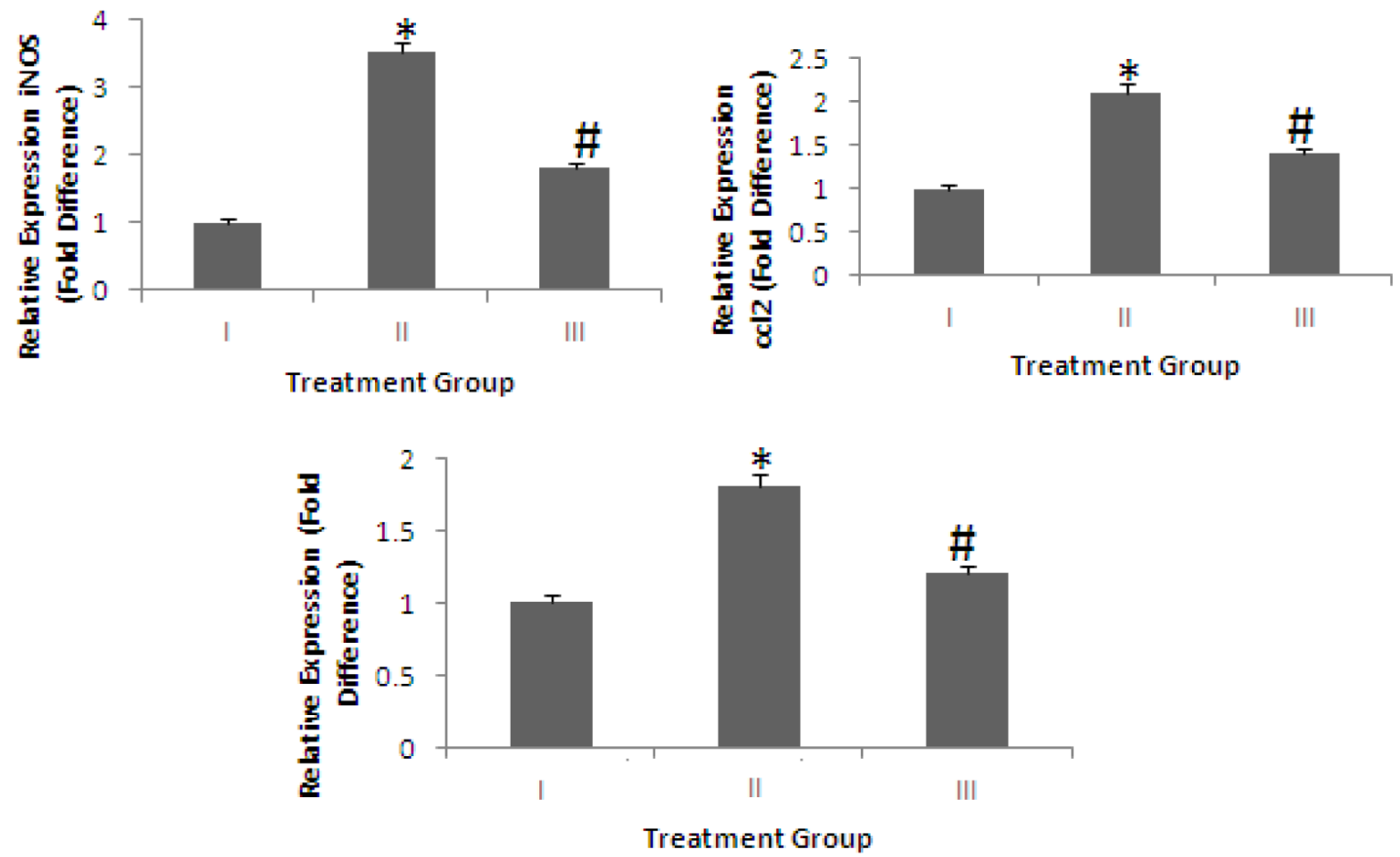

Figure 2: mRNA expression of genes encoding for neurotrophic factors and proinflammatory markers. Treatment I: Wild type (non-transgenic) control of the APPsw mice fed with regular diet; Treatment II: APPsw mice also fed with regular diet; and Treatment III: APPsw mice fed with $4 \%$ pomegranate fruit diet. The levels of two important neurotrophic factors, BDNF and IGF-1, and the proinflammatory cytokines, tnf- $\alpha$, il- $1 \beta$, iNOS, ccl2, and il-10, in the brains of mice fed $4 \%$ pomegranate diet for 15 months were determined using real-time polymerase chain reactions. Graphs are mean \pm S.E brains from tissue obtained from six rodents for each treatment group. Significance ${ }^{*} p<0.01$ compared to wild-type mice fed with regular diet, ${ }^{*} p<0.01$ compared to APPsw transgenic mice fed with regular diet. 


\section{Autophagy is enhanced by long-term supplementation with $4 \%$ pomegranates in APPsw/Tg 2576}

Apart from the improvements in synaptic protein expression and inhibition of neuroinflammation, we assessed the effects of $4 \%$ pomegranate supplementation on autophagy. We observed that dietary supplementation with $4 \%$ pomegranates significantly induced autophagy, as shown by increased protein expression of Beclin-1 (bcl1) and Lipidated LC-3 (LC-3 type II) $(p<0.05)$ (Figure 3).

(A)

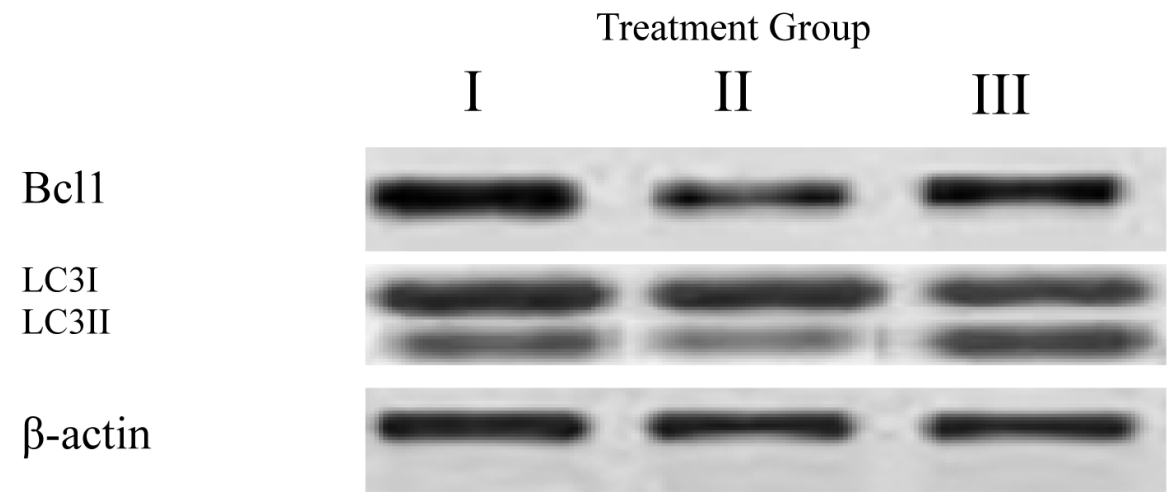

(B)
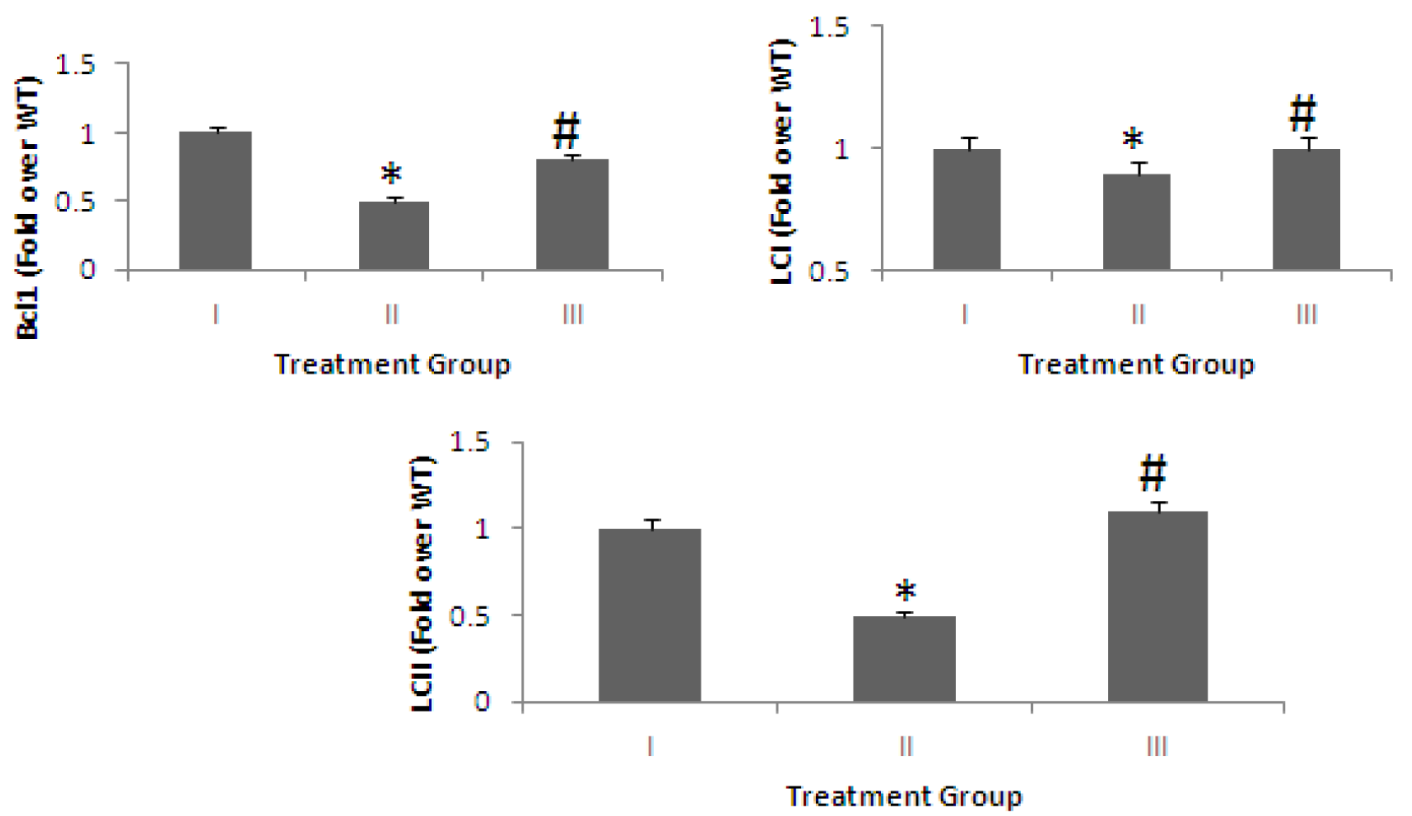

Figure 3: Protein expression of autophagic markers following long-term supplementation with $4 \%$ pomegranates in APPsw/Tg 2576. The levels of autophagic markers, LC3 and bcl1, in the brains of mice fed $4 \%$ pomegranate diet for 15 months were determined using western blot analysis. Treatment I: Wild type (non-transgenic) control of the APPsw mice fed with regular diet; Treatment II: APPsw mice also fed with regular diet; and Treatment III: APPsw mice fed with 4\% pomegranate fruit diet. A. The blot shown is representative tracings of an experiment done six times. B. Graphs are mean \pm S.E brains from tissue obtained from six rodents for each treatment group. Each bar of the quantification graph represents the corresponding band for each age group. Significance ${ }^{*} p<0.01$ compared to wild-type mice fed with regular diet, ${ }^{\#} p<0.01$ compared to APPsw transgenic mice fed with regular diet. 


\section{The PI3K/Akt/mTOR signaling pathway is activated in APPsw/Tg 2576 treated with 4\% pomegranates for 15 months}

The activation of protein translation by the PI3K/ Akt/mTOR signaling pathway is a key regulator of synaptic plasticity [52]. We assessed the effect of supplementation with $4 \%$ pomegranates on activation of the PI3K and mTOR by determining the phosphorylation levels of Akt and p70 S6 kinase (p70S6K) using immunoblotting. Our data shows that phosphorylation of Akt, mTOR and p70S6K were significantly increased in the brain of $4 \%$ pomegranate-treated APPsw/Tg 2576 mice compared to APPsw/Tg 2576 mice receiving a standard chow diet $(p<0.05)$ (Figure 4$)$.

\section{Treatment with $4 \%$ pomegranates lowered amyloidogenic processing of APP in APPsw/Tg 2576 after 15 months}

We also investigated the effect of a $4 \%$ pomegranate diet on APP processing by Western blot (Figure 5). Increased APP anabolism may stimulate APP secretion. Therefore, we determined the effect of $4 \%$ pomegranate diet on full-length APP levels. We used a polyclonal carboxyl-terminal APP antibody that is specific to both Carboxyl-Terminal Fragment $\beta$ (CTF $\beta$ ) and CarboxylTerminal Fragment $\alpha(\mathrm{CTF} \alpha)$. No significant difference was observed on APP steady-state protein expression in the brains of APPsw/Tg 2576 fed standard chow diet, and APPsw/Tg 2576 mice administered a $4 \%$ pomegranate diet. This suggests that pomegranates and their constituents do not influence APP synthesis. BACE1 is responsible for the proteolytic cleavage of full length APP to form SAPP $\beta$ and CTF $\beta$. We observed a significant increase in BACE1, SAPP $\beta$, and CTF $\beta$ expression in the brains of APPsw/Tg 2576 compared to wild-type mice $(p<0.05)$. After treatment with a $4 \%$ pomegranate diet, the expression of BACE1, sAPP $\beta$, and CTF $\beta$ in APPsw/ Tg 2576 mice was significantly decreased after 15 months $(p<0.05)$.

$\mathrm{CTF} \alpha$ is produced as a by-product of $\alpha$-secretase cleavage, which is regulated by the metalloproteases, ADAM10 and ADAM17 [53-59]. The protein expression of CTF $\alpha$ was significantly increased by more than 2 -fold in APPsw/Tg 2576 mice brains compared with wild-type controls $(p<0.05)$. However, no significant difference on the levels of CTF $\alpha$, ADAM10 and ADAM17 was observed after pomegranate treatment. This suggests that a pomegranate-rich diet has no effect on the modulation of the $\alpha$-secretase pathway.

\section{DISCUSSION}

The present study demonstrated for the first time that pomegranate diet administered for 15 months enhanced synaptic plasticity by increasing the expression of synaptic proteins, including PSD-95, Munc18-1, SNAP25, synaptophysin, p-CaMKII $\alpha /$ CaMKII $\alpha$, and $\mathrm{pCREB} / \mathrm{CREB}$, inhibited neuroinflammation, promoted autophagy, activated PI3K-Akt-mTOR signaling pathway, and altered APP processing in APPsw/Tg 2576 mice.

The beneficial effects of fruits and vegetables in health and ageing have been well emphasized. However, few studies have demonstrated the neuroprotective effects of pomegranate consumption in preclinical and clinical trials for AD. Pomegranates have been shown to consist of numerous phytochemicals, with potent antioxidant and anti-inflammatory properties. Indeed, our qualitative analysis using high precision liquid chromatography (HPLC) has shown that pomegranate extracts contain active components in significant amounts of ellagitannin, such as punicalin and punicalagin, and flavonoids, such as kaempferol and quercetin derivatives (Data not shown). Apart from demonstrating potent antioxidant and antiinflammatory properties, ellagic acid and punicalagin, are $\beta$-secretase inhibitors [60]. As well, recent studies have suggested that quercetin may exert its beneficial effects independent of its antioxidant properties. Quercetin can also modulate pathways associated with mitochondrial biogenesis, mitochondrial membrane potential, oxidative respiration and ATP anabolism, intra-mitochondrial redox status, and subsequently, mitochondria-induced apoptosis [61]. Taken together, the active phytochemicals present in pomegranate extracts possess beneficial effects on brain function and can mitigate different hallmarks of neurodegeneration.

We and others have previously shown that dietary pomegranate supplementation can attenuate chronic oxidative stress in $\mathrm{APPsw} / \mathrm{Tg} 2576$ mice, reduce acetylcholinesterase activity and plasma $A \beta_{1-40}$ and $A \beta_{1}$. ${ }_{42}$ levels, and ameliorate memory and anxiety-related behavioural deficits, and improve spatial learning ability in vivo, consistent with our findings [47-49]. Biological extracts derived from the pomegranate rind have been shown to inhibit BACE1 activity in vitro. Pomegranate consumption has also been shown to improve brain function in several neurodegenerative disease models [62]. For instance, pomegranates attenuated 1-methyl4-phenyl-1,2,3,6-tetrahydropyridine-induced oxidative stress and apoptosis in neuronal cells [63]. Reduced brain damage was also observed in postnatal day 7 pups exposed maternally to hypoxic insult $[45,46,64]$. Improvements in motor behaviour have also been reported in mice exposed to cytotoxic levels of proton radiation following pomegranate consumption [65]. Ellagic acid possesses potent neuroprotective effects through its free radical scavenging properties, iron chelation, activation 


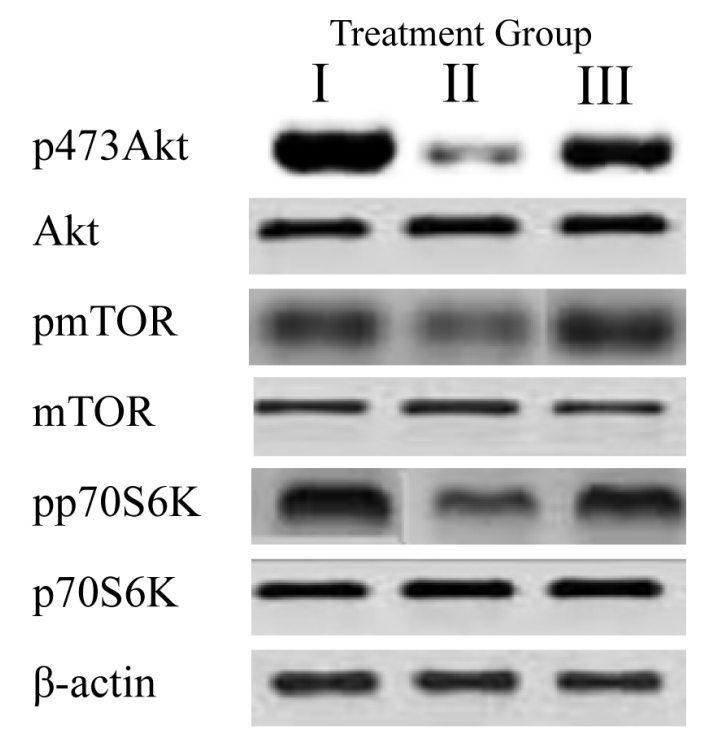

(B)
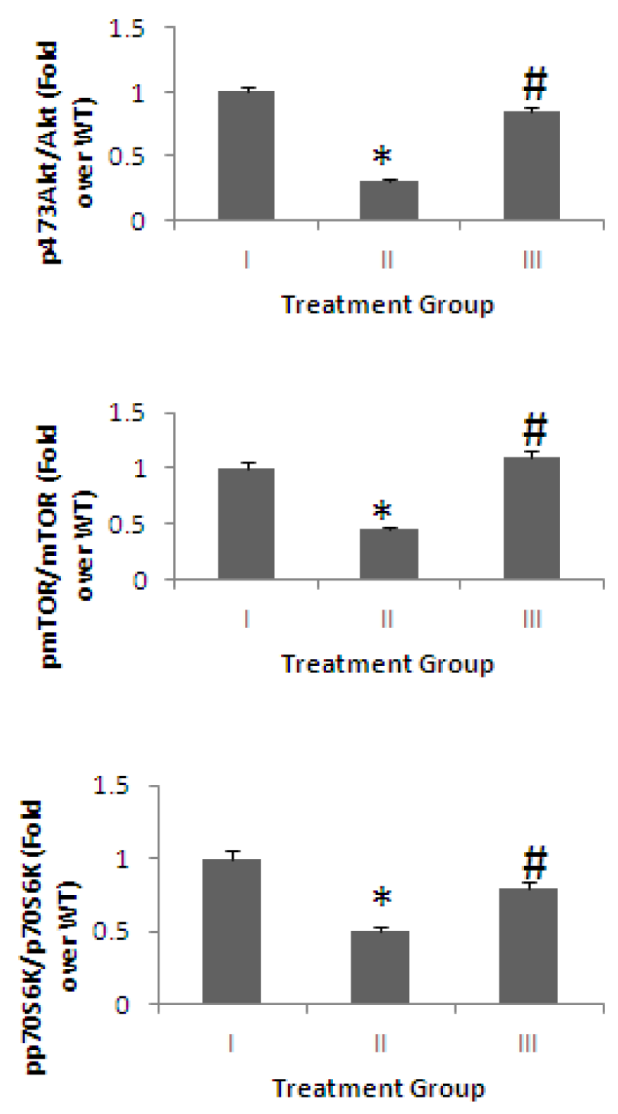

Figure 4: mTOR signaling pathway in brain homogenates detected by Western blot analysis. The levels Akt, mTOR and p70S6K, and their phosphorylated forms in the brains of mice fed $4 \%$ pomegranate diet for 15 months. Treatment I: Wild type (nontransgenic) control of the APPsw mice fed with regular diet; Treatment II: APPsw mice also fed with regular diet; and Treatment III: APPsw mice fed with $4 \%$ pomegranate fruit diet. A. The blot shown is representative tracings of an experiment done six times. B. Graphs are mean \pm S.E brains from tissue obtained from six rodents for each treatment group. Each bar of the quantification graph represents the corresponding band for each age group. Significance ${ }^{*} p<0.01$ compared to wild-type mice fed with regular diet, ${ }^{*} p<0.01$ compared to APPsw transgenic mice fed with regular diet. 
APP

BACE1

CTF $\beta$

CTF $\alpha$

sAPP

ADAM10

ADAM17

$\beta$-actin
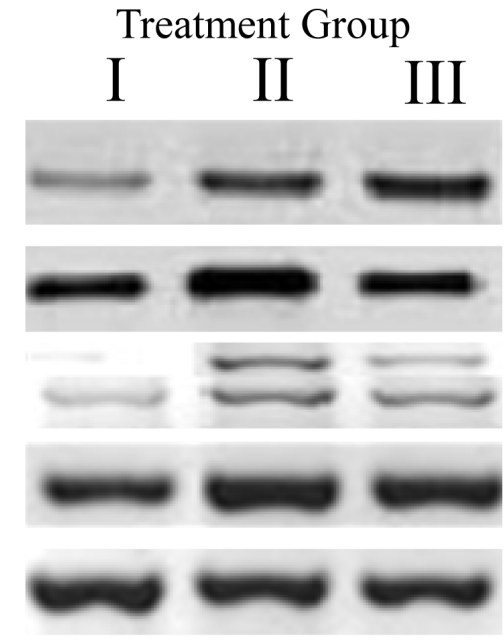

(B)
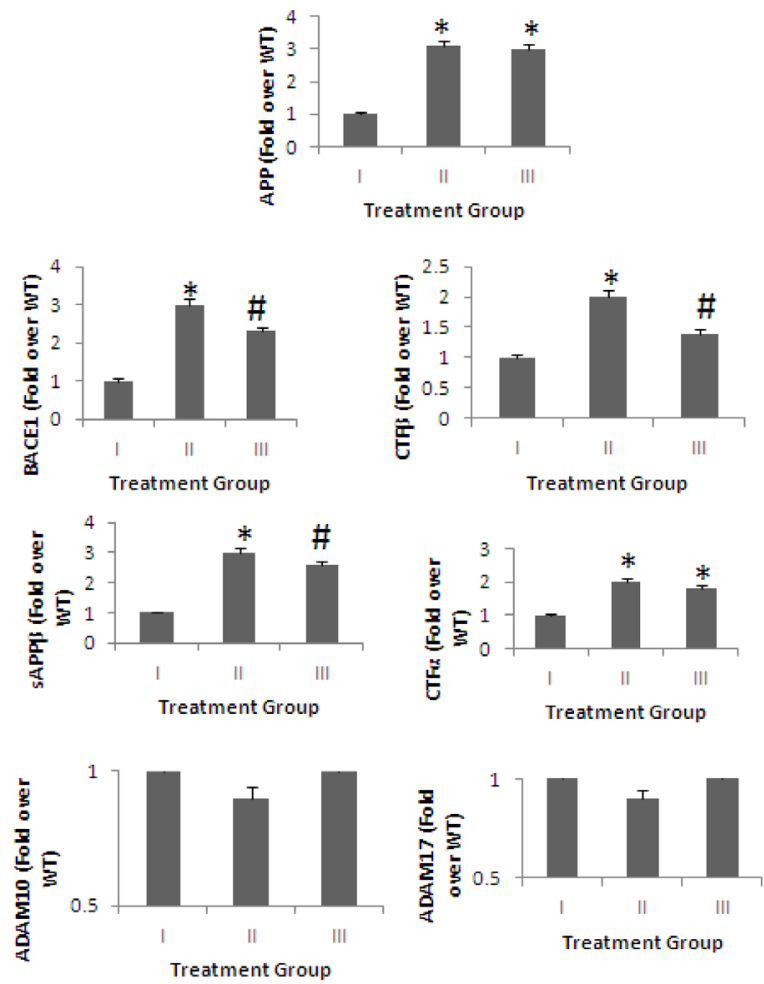

Figure 5: BACE1 and APP processing in brain homogenates detected by Western blot analysis. The levels APP, BACE1, $\mathrm{CTF} \alpha, \mathrm{CTF} \beta$, sAPP $\beta$, ADAM10 and ADAM17 in the brains of mice fed 4\% pomegranate diet for 15 months. Treatment I: Wild type (non-transgenic) control of the APPsw mice fed with regular diet; Treatment II: APPsw mice also fed with regular diet; and Treatment III: APPsw mice fed with 4\% pomegranate fruit diet. A. The blot shown is representative tracings of an experiment done six times. B.Graphs are mean \pm S.E brains from tissue obtained from six rodents for each treatment group. Each bar of the quantification graph represents the corresponding band for each age group. Significance ${ }^{*} p<0.01$ compared to wild-type mice fed with regular diet, ${ }^{\#} p<0.01$ compared to APPsw transgenic mice fed with regular diet. 
of different cell signaling pathways, and mitigation of mitochondrial dysfunction.

Synaptic loss represents another pathological hallmark in AD. It is well established that alterations in the expression of synaptic proteins precedes neuronal loss in $\mathrm{AD}$ [66-69]. Therefore, we analyzed the changes in protein expression of several important synaptic proteins associated with maintenance of normal plasticity. We found a significant reduction in the presynaptic marker synaptophysin and postsynaptic marker PSD-95 in APPsw/ Tg 2576 mice after 15 months, and supplementation with a $4 \%$ pomegranate diet upregulated the expression of these proteins. Increased calcium influx through activated N-methyl-D-aspartate (NMDA) receptors induces autophosphorylation of Calcium/Calmodulin-Dependent Protein Kinase II (CaMKII), and enhances translocation of CaMKII to the post-synapse. This leads to the activation of Cyclic AMP-Response Element Binding Protein (CREB). This nuclear transcription factor is associated with the formation of long-term memory [70-75]. We found that the ratio of pCaMKII $\alpha / \mathrm{CaMKII} \alpha$ and pCREB/ CREB declined in APPsw/Tg 2576 mice at 15 months compared to wild-type mice. However, supplementation with $4 \%$ pomegranates significantly improved the ratio of $\mathrm{pCaMKII} \alpha / \mathrm{CaMKII} \alpha$ and $\mathrm{pCREB} / \mathrm{CREB}$ declined in APPsw/Tg 2576 mice. Our data collectively suggests that a pomegranate-rich diet may attenuate deficits in memory and cognition through upregulation of signalling pathways associated with synaptic plasticity.

Inflammation has been shown to represent a doubleedged sword in $\mathrm{AD}$ pathogenesis - it is deleterious to neurons, but is necessary to facilitate the clearance of neurotoxic $A \beta$ deposits [76]. Upregulation of important inflammatory transcripts, thf- $\alpha, i l-1 \beta, i N O S, c c l 2$, and il-1 were observed in APPsw/Tg 2576 mice compared to wild-type mice. However, supplementation with $4 \%$ pomegranate diet reduced the expression of these proinflammatory gene transcripts. We also examined whether the anti-inflammatory effects of a pomegranate diet may be due to an autophagic-dependent effect. Our data shows that $4 \%$ pomegranate diet increased the protein expression of bcl1 and LC-3 type II. Bcl1 is an essential protein that enhances microglial phagocytosis, and autophagy is crucial for the catabolism of abnormal $\mathrm{A} \beta$ aggregates by activated microglial cells in the brain [77-80].

Another protein associated with synaptic plasticity is mTOR [81, 82]. Increased calcium influx through activated NMDA receptors can activate mTOR, thus promoting the anabolism of protein, including NR1, CaMKII $\alpha$, PSD-95, Arc, and protein kinase $\mathrm{C}$ isoform protein kinase $\mathrm{M}$ zeta, to stimulate synaptic plasticity [82-89]. Deregulation of mTOR signalling has been associated with cognitive and behavioural deficits [90-95]. Increased APP processing and the $\mathrm{A} \beta$ peptides can inhibit the PI3K-Akt-mTOR pathway, and reduced mTOR activity has been reported in both APPsw/Tg 2576 mice and human AD patients [96116]. Likewise, we found that phosphorylation of mTOR was significantly decreased in 15 month old APPsw/Tg 2576 mice. These pathological changes were improved following treatment with $4 \%$ pomegranate diet. Therefore, another mechanism by which pomegranates may improve synaptic function may be through activation of the PI3KAkt-mTOR pathway.

We also investigated whether a pomegranate diet can change the proteolytic processing of APP, by measuring the protein expression of BACE1. In line with previous studies, we found that BACE1 protein levels were significantly increased 15 month old APPsw/Tg 2576 mice compared to wild-type controls [62]. Treatment with 4\% pomegranates significantly reduced BACE1 expression. Therefore, BACE1 inhibition may represent a valuable target for reducing $\mathrm{A} \beta$ levels in $\mathrm{AD}$ [117]. Additionally, the protein expression of sAPP $\beta$ and CTF $\beta$, were also reduced 15 month old APPsw/Tg 2576 mice exposed to 4\% pomegranate diet. These results provide additional support for the inhibitory effects of pomegranate consumption of BACE1 activity in AD.

The proteolytic cleavage of APP is initiated non-amyloidogenically by $\alpha$-secretase. ADAM10 and ADAM17 are two main enzymes with $\alpha$-secretase activity [118-120]. Although ADAM10 is necessary for APP $\alpha$-secretase cleavage, ADAM17 may also be involved, although it is not crucial [121]. No significant difference in the expression of ADAM10 and ADAM17 were observed between 15 month old APPsw/Tg 2576 mice and wildtype mice. An increase in CTF $\alpha$ level observed in the APPsw/Tg 2576 mice compared to wild-type mice may be due to increased levels of APP, the $\alpha$-secretase substrate, or $\alpha$-secretase activity in APPsw/Tg 2576 mice. The expression of ADAM10, ADAM17, and CTF $\alpha$, remained unchanged, following treatment with $4 \%$ pomegranates, suggesting that $\alpha$-secretase activity is independent of pomegranate-mediated APP processing.

In conclusion, this study has demonstrated for the first time that long-term supplementation with a $4 \%$ pomegranate diet can enhance synaptic plasticity in APPsw/Tg 2576 mice, leading to reduced cerebral A $\beta$ levels, cleavage of CTF $\beta$ and SAPP $\beta$, and BACE1 protein expression. Together with other mechanisms, such as inhibition of neuroinflammation, and increased autophagy, pomegranates may represent alternative treatment to lower AD pathology.

\section{MATERIALS AND METHODS}

\section{Collection and preparation}

Fresh pomegranate fruits were collected from AlJabal Al-Akdhar farms, Oman. Then, pomegranates were 
frozen $\left(-40^{\circ} \mathrm{C}\right)$ for 5 days. After that, the samples were ground into a fine powder using a coffee grinder.

\section{Diet preparation for the animals}

The ground pomegranates were sent to USA to prepare the diet for the mice. The diet was prepared by mixing the pomegranate $(4 \%)$ with regular diet as per National Institutes of Health, USA protocol by Research Diet Inc, NJ, USA.

\section{Animals and treatment}

Twelve transgenic female (APPsw/Tg 2576) and 6 wild-type control (non-transgenic) mice (Taconic form, NY, USA) were used. Animals were quarantined for 7 days after shipping and individually housed in plastic cages in an animal room, which was maintained at a temperature of $22 \pm 2^{\circ} \mathrm{C}$, a relative humidity of $50 \pm 10 \%$, and a 12-h light/dark automatic light cycle (light: 08:0020:00 h). Tap water was offered ad libitum throughout the study. The study was approved by the Animal Care and Use Committee of the Sultan Qaboos University, Oman (SQU/AEC/2010-11/3).

All these animals are free from pathogens and viruses. Experimental period commenced from the age of 4 months. The animals were divided into three groups: Treatment I: Wild type (non-transgenic) control of the APPsw mice fed with regular diet; Treatment II: APPsw mice also fed with regular diet; and Treatment III: APPsw mice fed with $4 \%$ pomegranate fruit diet. These experimental and control mice were fed a $4 \%$ pomegranate or control diet for 15 months. All animal experiments in the present study were complied with the Animal Care and Use Committee of the Sultan Qaboos University, Oman.

\section{Tissue collection}

The brains were carefully removed, and homogenization in 9 volumes $(1: 9 \mathrm{w} / \mathrm{v})$ of cold saline, and centrifugation for supernatant collection. The samples of the brain were stored at $-80^{\circ} \mathrm{C}$ until measurement.

\section{Reverse transcription and quantitative PCR for analysis of gene transcripts}

For the gene expression studies RNA was extracted from treated human astrocytes and neurons using the RNeasy mini kits (Qiagen, Hilden, Germany). The cDNA was prepared using the SuperScript III First-Strand Synthesis System and random hexamers (Invitrogen Corporation). Q-PCR was carried out using the Mx3500P Real-Time PCR system (Stratagene, NSW, Australia) with the Taqman gene expression assays of mouse tumour necrosis factor- $\alpha$ (tnf- $\alpha)$, interleukin 1- $\beta$ (i1-1 $\beta)$, inducible nitric oxide synthase [122], chemokine ( $C-C$ motif) ligand 2 (ccl2), interleukin 1- $\beta$ (il-10), brain-derived neurotrophic factor (bdnf), insulin-like growth factor (igf)-1, and glyceraldehyde 3-phosphate dehydrogenase (gapdh) (all from Life Technologies). at $4{ }^{\circ} \mathrm{C}$. The

\section{Western blotting}

The brains of animals were dissected on ice and immediately processed. Briefly, hippocampal tissue were homogenized in RIPA buffer $(50 \mathrm{mM}$, Tris- $\mathrm{Cl}, \mathrm{pH} 7.5$, $150 \mathrm{mM} \mathrm{NaCl}, 1 \% \mathrm{NP}-40,0.5 \%$ sodium deoxycholate, and $1 \%$ SDS), supplemented with a protease inhibitor cocktail (Sigma-Aldrich P8340) and phosphatase inhibitors $\left(50 \mathrm{mM} \mathrm{NaF}, 1 \mathrm{mM} \mathrm{Na} \mathrm{VO}_{4}\right.$ and $30 \mu \mathrm{M}$ $\mathrm{Na}_{4} \mathrm{P}_{2} \mathrm{O}_{7}$ ), using a Potter homogenizer and then passed sequentially through different calibre syringes. Protein samples were centrifuged at $14000 \mathrm{rpm}$ at $4^{\circ} \mathrm{C}$ twice for $15 \mathrm{~min}$ [26]. Protein concentration was determined using the BCA Protein Assay Kit (Pierce Biotechnology, Rockford, IL). $20 \mu \mathrm{g}$ of hippocampal samples were resolved by $10 \%$ SDS-PAGE and transferred to a PVDF membrane. The reactions were followed by incubation with a primary antibody; then a secondary anti-goat peroxidase conjugated antibody (Pierce) was used and developed using an ECL kit (Western Lightning Plus ECL, PerkinElmer).

\section{Statistical analysis}

Results are expressed as mean \pm standard error. Data were analysed by one-way ANOVA, followed by Bonferroni's post hoc test. $\mathrm{p} \leq 0.05$ was considered as statistically significant. Statistical analysis was performed using Prism software (GraphPad Software Inc).

\section{ACKNOWLEDGMENTS}

NB is the recipient of an Alzheimer's Australia Viertel Foundation and National Health and Medical Research Centre Postdoctoral Research Fellowship at the University of New South Wales. The authors thank the Rebecca Cooper Medical Research Foundation for their ongoing financial support.

\section{CONFLICTS OF INTEREST}

The authors declare no conflict of interests in regards to this manuscript.

\section{GRANT SUPPORT}

This work was supported by a research grant from 
the Research Council Oman (RC/AGR/Food/11/01).

\section{Authors' Contribution}

$\mathrm{NB}$ and MME designed and conducted all the experiments and wrote the manuscript. AP, SA, TM, JT, LO, and PS provided conceptual help and reagents throughout experimentation. SS contributed to specific experimental designs. NB, MME, and GJG were involved in conception and design, data analysis and interpretation, manuscript writing and final approval of the manuscript.

\section{REFERENCES}

1. Wimo A, Jonsson L, Bond J, Prince M, Winblad B, Alzheimer Disease I. The worldwide economic impact of dementia 2010. Alzheimers Dement. 2013; 9: 1-11 e3. doi: 10.1016/j.jalz.2012.11.006.

2. Prince M, Bryce R, Albanese E, Wimo A, Ribeiro W, Ferri $\mathrm{CP}$. The global prevalence of dementia: a systematic review and metaanalysis. Alzheimers Dement. 2013; 9: 63-75 e2. doi: 10.1016/j.jalz.2012.11.007.

3. Albanese E, Lombardo FL, Prince MJ, Stewart R. Dementia and lower blood pressure in Latin America, India, and China: a 10/66 cross-cohort study. Neurology. 2013; 81: 228-35. doi: 10.1212/WNL.0b013e31829bfe66.

4. Albanese E, Taylor C, Siervo M, Stewart R, Prince MJ, Acosta D. Dementia severity and weight loss: a comparison across eight cohorts. The 10/66 study. Alzheimers Dement. 2013; 9: 649-56. doi: 10.1016/j.jalz.2012.11.014.

5. Prince MJ. Dementia in China: east-west collaboration bears fruit. Lancet. 2013; 381: 1967-8. doi: 10.1016/S01406736(13)60770-9.

6. Gardner RC, Valcour V, Yaffe K. Dementia in the oldest old: a multi-factorial and growing public health issue. Alzheimers Res Ther. 2013; 5: 27. doi: 10.1186/alzrt181.

7. Licastro F, Porcellini E, Forti P, Buscema M, Carbone I, Ravaglia G, Grossi E. Multi factorial interactions in the pathogenesis pathway of Alzheimer's disease: a new risk charts for prevention of dementia. Immun Ageing. 2010; 7 Suppl 1: S4. doi: 10.1186/1742-4933-7-S1-S4.

8. Zetterberg H, Blennow K. Cerebrospinal fluid biomarkers for Alzheimer's disease: more to come? J Alzheimers Dis. 2013; 33 Suppl 1: S361-9. doi: 10.3233/JAD-2012-129035.

9. Wyss-Coray T, Rogers J. Inflammation in Alzheimer disease-a brief review of the basic science and clinical literature. Cold Spring Harb Perspect Med. 2012; 2: a006346. doi: 10.1101/cshperspect.a006346.

10. Liu XH, Geng Z, Yan J, Li T, Chen Q, Zhang QY, Chen ZY. Blocking GSK3beta-mediated dynamin1 phosphorylation enhances BDNF-dependent TrkB endocytosis and the protective effects of BDNF in neuronal and mouse models of Alzheimer's disease. Neurobiol Dis. 2015; 74: 377-91. doi: 10.1016/j.nbd.2014.11.020.

11. Xu J, Jiang Y, Wang J, Shi X, Liu Q, Liu Z, Li Y, Scott MJ, Xiao G, Li S, Fan L, Billiar TR, Wilson MA, et al. Macrophage endocytosis of high-mobility group box 1 triggers pyroptosis. Cell Death Differ. 2014; 21: 1229-39. doi: 10.1038/cdd.2014.40.

12. Zou C, Shi Y, Ohli J, Schuller U, Dorostkar MM, Herms J. Neuroinflammation impairs adaptive structural plasticity of dendritic spines in a preclinical model of Alzheimer's disease. Acta Neuropathol. 2016; 131: 235-46. doi: 10.1007/s00401-015-1527-8.

13. Minter MR, Taylor JM, Crack PJ. The contribution of neuroinflammation to amyloid toxicity in Alzheimer's disease. J Neurochem. 2016; 136: 457-74. doi: 10.1111/ jnc. 13411 .

14. Wang SW, Yang SG, Liu W, Zhang YX, Xu PX, Wang T, Ling TJ, Liu RT. Alpha-tocopherol quinine ameliorates spatial memory deficits by reducing beta-amyloid oligomers, neuroinflammation and oxidative stress in transgenic mice with Alzheimer's disease. Behav Brain Res. 2016; 296: 109-17. doi: 10.1016/j.bbr.2015.09.003.

15. Wilkins HM, Swerdlow RH. Relationships Between Mitochondria and Neuroinflammation: Implications for Alzheimer's Disease. Curr Top Med Chem. 2016; 16: 84957.

16. Naidoo R, Knapp M. Studies of lipid peroxidation products in cerebrospinal fluid and serum in multiple sclerosis and other conditions. Clin Chem. 1992; 38: 2449-54.

17. Parvathy S, Hussain I, Karran EH, Turner AJ, Hooper NM. Alzheimer's amyloid precursor protein alpha-secretase is inhibited by hydroxamic acid-based zinc metalloprotease inhibitors: similarities to the angiotensin converting enzyme secretase. Biochemistry. 1998; 37: 1680-5. doi: 10.1021/ bi972034y.

18. Parvathy S, Turner AJ, Hooper NM. Inhibition of alphaSecretase by Zinc Metalloproteinase Inhibitors. Methods Mol Med. 2000; 32: 203-15. doi: 10.1385/1-59259-1957:203.

19. Cai J, Qi X, Kociok N, Skosyrski S, Emilio A, Ruan Q, Han S, Liu L, Chen Z, Bowes Rickman C, Golde T, Grant $\mathrm{MB}$, Saftig P, et al. beta-Secretase (BACE1) inhibition causes retinal pathology by vascular dysregulation and accumulation of age pigment. EMBO Mol Med. 2012; 4: 980-91. doi: 10.1002/emmm.201101084.

20. Ghosh AK, Osswald HL. BACE1 (beta-secretase) inhibitors for the treatment of Alzheimer's disease. Chem Soc Rev. 2014; 43: 6765-813. doi: 10.1039/c3cs60460h.

21. Laird FM, Cai H, Savonenko AV, Farah MH, He K, Melnikova T, Wen H, Chiang HC, Xu G, Koliatsos VE, Borchelt DR, Price DL, Lee HK, et al. BACE1, a major determinant of selective vulnerability of the brain to amyloid-beta amyloidogenesis, is essential for cognitive, emotional, and synaptic functions. J Neurosci. 2005; 25: 11693-709. doi: 10.1523/JNEUROSCI.2766-05.2005. 
22. Ohno M, Cole SL, Yasvoina M, Zhao J, Citron M, Berry R, Disterhoft JF, Vassar R. BACE1 gene deletion prevents neuron loss and memory deficits in 5XFAD APP/PS1 transgenic mice. Neurobiol Dis. 2007; 26: 134-45. doi: 10.1016/j.nbd.2006.12.008.

23. Selkoe DJ, Wolfe MS. In search of gamma-secretase: presenilin at the cutting edge. Proc Natl Acad Sci U S A. 2000; 97: 5690-2.

24. Haxaire C, Turpin FR, Potier B, Kervern M, Sinet PM, Barbanel G, Mothet JP, Dutar P, Billard JM. Reversal of age-related oxidative stress prevents hippocampal synaptic plasticity deficits by protecting D-serine-dependent NMDA receptor activation. Aging Cell. 2012; 11: 336-44. doi: 10.1111/j.1474-9726.2012.00792.x.

25. Vincent AJ, Gasperini R, Foa L, Small DH. Astrocytes in Alzheimer's disease: emerging roles in calcium dysregulation and synaptic plasticity. J Alzheimers Dis. 2010; 22: 699-714. doi: 10.3233/JAD-2010-101089.

26. Zhang H, Liu J, Sun S, Pchitskaya E, Popugaeva E, Bezprozvanny I. Calcium signaling, excitability, and synaptic plasticity defects in a mouse model of Alzheimer's disease. J Alzheimers Dis. 2015; 45: 561-80. doi: 10.3233/ JAD-142427.

27. Selkoe DJ, Schenk D. Alzheimer's disease: molecular understanding predicts amyloid-based therapeutics. Annu Rev Pharmacol Toxicol. 2003; 43: 545-84. doi: 10.1146/ annurev.pharmtox.43.100901.140248.

28. Selkoe DJ. Alzheimer's disease is a synaptic failure. Science. 2002; 298: 789-91. doi: 10.1126/science.1074069.

29. Garelick MG, Kennedy BK. TOR on the brain. Exp Gerontol. 2011; 46: 155-63. doi: 10.1016/j. exger.2010.08.030.

30. Pagliarulo C, De Vito V, Picariello G, Colicchio R, Pastore G, Salvatore P, Volpe MG. Inhibitory effect of pomegranate (Punica granatum L.) polyphenol extracts on the bacterial growth and survival of clinical isolates of pathogenic Staphylococcus aureus and Escherichia coli. Food Chem. 2016; 190: 824-31. doi: 10.1016/j.foodchem.2015.06.028.

31. Li X, Wasila H, Liu L, Yuan T, Gao Z, Zhao B, Ahmad I. Physicochemical characteristics, polyphenol compositions and antioxidant potential of pomegranate juices from 10 Chinese cultivars and the environmental factors analysis. Food Chem. 2015; 175: 575-84. doi: 10.1016/j. foodchem.2014.12.003.

32. Trigueros L, Wojdylo A, Sendra E. Antioxidant activity and protein-polyphenol interactions in a pomegranate (Punica granatum L.) yogurt. J Agric Food Chem. 2014; 62: 641725. doi: 10.1021/jf501503h.

33. Chen B, Longtine MS, Nelson DM. Punicalagin, a polyphenol in pomegranate juice, downregulates p53 and attenuates hypoxia-induced apoptosis in cultured human placental syncytiotrophoblasts. Am J Physiol Endocrinol Metab. 2013; 305: E1274-80. doi: 10.1152/ ajpendo.00218.2013.
34. Yan H, Peng KJ, Wang QL, Gu ZY, Lu YQ, Zhao J, Xu F, Liu YL, Tang Y, Deng FM, Zhou P, Jin JG, Wang XC. Effect of pomegranate peel polyphenol gel on cutaneous wound healing in alloxan-induced diabetic rats. Chin Med J (Engl). 2013; 126: 1700-6.

35. Neyrinck AM, Van Hee VF, Bindels LB, De Backer F, Cani PD, Delzenne NM. Polyphenol-rich extract of pomegranate peel alleviates tissue inflammation and hypercholesterolaemia in high-fat diet-induced obese mice: potential implication of the gut microbiota. Br J Nutr. 2013; 109: 802-9. doi: 10.1017/S0007114512002206.

36. Tsang C, Smail NF, Almoosawi S, Davidson I, Al-Dujaili EA. Intake of polyphenol-rich pomegranate pure juice influences urinary glucocorticoids, blood pressure and homeostasis model assessment of insulin resistance in human volunteers. J Nutr Sci. 2012; 1: e9. doi: 10.1017/ jns.2012.10.

37. Haidari M, Ali M, Ward Casscells S, 3rd, Madjid M. Pomegranate (Punica granatum) purified polyphenol extract inhibits influenza virus and has a synergistic effect with oseltamivir. Phytomedicine. 2009; 16: 1127-36. doi: 10.1016/j.phymed.2009.06.002.

38. Rasheed Z, Akhtar N, Anbazhagan AN, Ramamurthy S, Shukla M, Haqqi TM. Polyphenol-rich pomegranate fruit extract (POMx) suppresses PMACI-induced expression of pro-inflammatory cytokines by inhibiting the activation of MAP Kinases and NF-kappaB in human KU812 cells. J Inflamm (Lond). 2009; 6: 1. doi: 10.1186/1476-9255-6-1.

39. Faria A, Monteiro R, Azevedo I, Calhau C. Comment on safety and antioxidant activity of a pomegranate ellagitannin-enriched polyphenol dietary supplement in overweight individuals with increased waist size. J Agric Food Chem. 2008; 56: 12143-4; author reply 5-6. doi: 10.1021/jf802383q.

40. Heber D, Seeram NP, Wyatt H, Henning SM, Zhang Y, Ogden LG, Dreher M, Hill JO. Safety and antioxidant activity of a pomegranate ellagitannin-enriched polyphenol dietary supplement in overweight individuals with increased waist size. J Agric Food Chem. 2007; 55: 10050-4. doi: 10.1021/jf071689v.

41. Tzulker R, Glazer I, Bar-Ilan I, Holland D, Aviram M, Amir R. Antioxidant activity, polyphenol content, and related compounds in different fruit juices and homogenates prepared from 29 different pomegranate accessions. J Agric Food Chem. 2007; 55: 9559-70. doi: 10.1021/jf071413n.

42. Zaid MA, Afaq F, Syed DN, Dreher M, Mukhtar H. Inhibition of UVB-mediated oxidative stress and markers of photoaging in immortalized $\mathrm{HaCaT}$ keratinocytes by pomegranate polyphenol extract POMx. Photochem Photobiol. 2007; 83: 882-8. doi: 10.1111/j.17511097.2007.00157.x.

43. Cerda B, Llorach R, Ceron JJ, Espin JC, Tomas-Barberan FA. Evaluation of the bioavailability and metabolism in the rat of punicalagin, an antioxidant polyphenol from pomegranate juice. Eur J Nutr. 2003; 42: 18-28. doi: 


\subsection{7/s00394-003-0396-4.}

44. Wang J, Rong X, Um IS, Yamahara J, Li Y. 55-week treatment of mice with the unani and ayurvedic medicine pomegranate flower ameliorates ageing-associated insulin resistance and skin abnormalities. Evid Based Complement Alternat Med. 2012; 2012: 350125. doi: 10.1155/2012/350125.

45. West T, Atzeva M, Holtzman DM. Pomegranate polyphenols and resveratrol protect the neonatal brain against hypoxic-ischemic injury. Dev Neurosci. 2007; 29: 363-72. doi: 10.1159/000105477.

46. Loren DJ, Seeram NP, Schulman RN, Holtzman DM. Maternal dietary supplementation with pomegranate juice is neuroprotective in an animal model of neonatal hypoxicischemic brain injury. Pediatr Res. 2005; 57: 858-64. doi: 10.1203/01.PDR.0000157722.07810.15.

47. Subash S, Essa MM, Al-Asmi A, Al-Adawi S, Vaishnav R, Braidy N, Manivasagam T, Guillemin GJ. Pomegranate from Oman Alleviates the Brain Oxidative Damage in Transgenic Mouse Model of Alzheimer's disease. J Tradit Complement Med. 2014; 4: 232-8. doi: 10.4103/22254110.139107.

48. Hartman RE, Shah A, Fagan AM, Schwetye KE, Parsadanian M, Schulman RN, Finn MB, Holtzman DM. Pomegranate juice decreases amyloid load and improves behavior in a mouse model of Alzheimer's disease. Neurobiol Dis. 2006; 24: 506-15. doi: 10.1016/j. nbd.2006.08.006.

49. Subash S, Braidy N, Essa MM, Zayana AB, Ragini V, A1Adawi S, Al-Asmi A, Guillemin GJ. Long-term (15 mo) dietary supplementation with pomegranates from Oman attenuates cognitive and behavioral deficits in a transgenic mice model of Alzheimer's disease. Nutrition. 2015; 31: 223-9. doi: 10.1016/j.nut.2014.06.004.

50. Agarwal S, Tannenberg RK, Dodd PR. Reduced expression of the inhibitory synapse scaffolding protein gephyrin in Alzheimer's disease. J Alzheimers Dis. 2008; 14: 313-21. doi:

51. Kallop DY, Meilandt WJ, Gogineni A, Easley-Neal C, Wu T, Jubb AM, Yaylaoglu M, Shamloo M, Tessier-Lavigne M, Scearce-Levie K, Weimer RM. A death receptor 6-amyloid precursor protein pathway regulates synapse density in the mature CNS but does not contribute to Alzheimer's disease-related pathophysiology in murine models. J Neurosci. 2014; 34: 6425-37. doi: 10.1523/ JNEUROSCI.4963-13.2014.

52. Siman R, Cocca R, Dong Y. The mTOR Inhibitor Rapamycin Mitigates Perforant Pathway Neurodegeneration and Synapse Loss in a Mouse Model of Early-Stage Alzheimer-Type Tauopathy. PLoS One. 2015; 10: e0142340. doi: 10.1371/journal.pone.0142340.

53. Retraction notice to: SIRT1 suppresses beta-amyloid production by activating the alpha-secretase gene ADAM10. Cell. 2014; 158: 959. doi: 10.1016/j.cell.2014.06.035.
54. Allinson TM, Parkin ET, Condon TP, Schwager SL, Sturrock ED, Turner AJ, Hooper NM. The role of ADAM10 and ADAM17 in the ectodomain shedding of angiotensin converting enzyme and the amyloid precursor protein. Eur J Biochem. 2004; 271: 2539-47. doi: 10.1111/j.14321033.2004.04184.x.

55. Harris B, Pereira I, Parkin E. Targeting ADAM10 to lipid rafts in neuroblastoma SH-SY5Y cells impairs amyloidogenic processing of the amyloid precursor protein. Brain Res. 2009; 1296: 203-15. doi: 10.1016/j. brainres.2009.07.105.

56. Kuhn PH, Wang H, Dislich B, Colombo A, Zeitschel U, Ellwart JW, Kremmer E, Rossner S, Lichtenthaler SF. ADAM10 is the physiologically relevant, constitutive alpha-secretase of the amyloid precursor protein in primary neurons. EMBO J. 2010; 29: 3020-32. doi: 10.1038/ emboj.2010.167.

57. Marcinkiewicz M, Seidah NG. Coordinated expression of beta-amyloid precursor protein and the putative betasecretase BACE and alpha-secretase ADAM10 in mouse and human brain. J Neurochem. 2000; 75: 2133-43.

58. Suh J, Choi SH, Romano DM, Gannon MA, Lesinski AN, Kim DY, Tanzi RE. ADAM10 missense mutations potentiate beta-amyloid accumulation by impairing prodomain chaperone function. Neuron. 2013; 80: 385-401. doi: 10.1016/j.neuron.2013.08.035.

59. Xu D, Sharma C, Hemler ME. Tetraspanin 12 regulates ADAM10-dependent cleavage of amyloid precursor protein. FASEB J. 2009; 23: 3674-81. doi: 10.1096/fj.09133462.

60. Kwak H-M, Jeon S-Y, Sohng B-H, Kim J-G, Lee J-M, Lee K-B, Jeong H-H, Hur J-M, Kang Y-H, Song K-S. $\beta$-Secretase (BACE1) inhibitors from pomegranate (Punica granatum) husk. Archives of pharmacal research. 2005; 28 : 1328-32.

61. de Oliveira MR, Nabavi SM, Braidy N, Setzer WN, Ahmad T, SF N. Quercetin and the mitochondria: A mechanistic view. Biotechnol Adv. 2015. doi: 10.1016/j. biotechadv.2015.12.014.

62. Kwak HM, Jeon SY, Sohng BH, Kim JG, Lee JM, Lee KB, Jeong HH, Hur JM, Kang YH, Song KS. beta-Secretase (BACE1) inhibitors from pomegranate (Punica granatum) husk. Arch Pharm Res. 2005; 28: 1328-32.

63. Braidy N, Selvaraju S, Essa MM, Vaishnav R, Al-Adawi S, Al-Asmi A, Al-Senawi H, Abd Alrahman Alobaidy A, Lakhtakia R, Guillemin GJ. Neuroprotective effects of a variety of pomegranate juice extracts against MPTPinduced cytotoxicity and oxidative stress in human primary neurons. Oxid Med Cell Longev. 2013; 2013: 685909. doi: 10.1155/2013/685909.

64. Weyl-Feinstein S, Markovics A, Eitam H, Orlov A, Yishay M, Agmon R, Miron J, Izhaki I, Shabtay A. Short communication: effect of pomegranate-residue supplement on Cryptosporidium parvum oocyst shedding in neonatal calves. J Dairy Sci. 2014; 97: 5800-5. doi: 10.3168/ 
jds.2013-7136.

65. Dulcich MS, Hartman RE. Pomegranate supplementation improves affective and motor behavior in mice after radiation exposure. Evid Based Complement Alternat Med. 2013; 2013: 940830. doi: 10.1155/2013/940830.

66. Caccamo A, Branca C, Talboom JS, Shaw DM, Turner D, Ma L, Messina A, Huang Z, Wu J, Oddo S. Reducing Ribosomal Protein S6 Kinase 1 Expression Improves Spatial Memory and Synaptic Plasticity in a Mouse Model of Alzheimer's Disease. J Neurosci. 2015; 35: 14042-56. doi: 10.1523/JNEUROSCI.2781-15.2015.

67. Kvartsberg H, Duits FH, Ingelsson M, Andreasen N, Ohrfelt A, Andersson K, Brinkmalm G, Lannfelt L, Minthon L, Hansson O, Andreasson U, Teunissen CE, Scheltens P, et al. Cerebrospinal fluid levels of the synaptic protein neurogranin correlates with cognitive decline in prodromal Alzheimer's disease. Alzheimers Dement. 2015; 11: 118090. doi: 10.1016/j.jalz.2014.10.009.

68. Sotiropoulos I, Sousa N. Tau as the Converging Protein between Chronic Stress and Alzheimer's Disease Synaptic Pathology. Neurodegener Dis. 2016; 16: 22-5. doi: 10.1159/000440844.

69. Tiwari SS, d'Orange M, Troakes C, Shurovi BN, Engmann O, Noble W, Hortobagyi T, Giese KP. Evidence that the presynaptic vesicle protein CSPalpha is a key player in synaptic degeneration and protection in Alzheimer's disease. Mol Brain. 2015; 8: 6. doi: 10.1186/s13041-0150096-z.

70. Muller M, Cardenas C, Mei L, Cheung KH, Foskett JK. Constitutive cAMP response element binding protein (CREB) activation by Alzheimer's disease presenilindriven inositol trisphosphate receptor (InsP3R) Ca2+ signaling. Proc Natl Acad Sci U S A. 2011; 108: 13293-8. doi: 10.1073/pnas.1109297108.

71. Pugazhenthi S, Wang M, Pham S, Sze CI, Eckman CB. Downregulation of CREB expression in Alzheimer's brain and in Abeta-treated rat hippocampal neurons. Mol Neurodegener. 2011; 6: 60. doi: 10.1186/1750-1326-6-60.

72. Saura CA, Valero J. The role of CREB signaling in Alzheimer's disease and other cognitive disorders. Rev Neurosci. 2011; 22: 153-69. doi: 10.1515/RNS.2011.018.

73. Scott Bitner R. Cyclic AMP response element-binding protein (CREB) phosphorylation: a mechanistic marker in the development of memory enhancing Alzheimer's disease therapeutics. Biochem Pharmacol. 2012; 83: 705-14. doi: 10.1016/j.bcp.2011.11.009.

74. Wang A, Bibb JA. Is CREB the angry bird that releases memory in Alzheimer's? Neuropsychopharmacology. 2011; 36: 2153-4. doi: 10.1038/npp.2011.126.

75. Yiu AP, Rashid AJ, Josselyn SA. Increasing CREB function in the CA1 region of dorsal hippocampus rescues the spatial memory deficits in a mouse model of Alzheimer's disease. Neuropsychopharmacology. 2011; 36: 2169-86. doi: 10.1038/npp.2011.107.
76. Liu Y, Walter S, Stagi M, Cherny D, Letiembre M, SchulzSchaeffer W, Heine H, Penke B, Neumann H, Fassbender K. LPS receptor (CD14): a receptor for phagocytosis of Alzheimer's amyloid peptide. Brain. 2005; 128: 1778-89. doi: 10.1093/brain/awh531.

77. Jaeger PA, Pickford F, Sun CH, Lucin KM, Masliah E, Wyss-Coray T. Regulation of amyloid precursor protein processing by the Beclin 1 complex. PLoS One. 2010; 5: e11102. doi: 10.1371/journal.pone.0011102.

78. Lucin KM, O’Brien CE, Bieri G, Czirr E, Mosher KI, Abbey RJ, Mastroeni DF, Rogers J, Spencer B, Masliah E, Wyss-Coray T. Microglial beclin 1 regulates retromer trafficking and phagocytosis and is impaired in Alzheimer's disease. Neuron. 2013; 79: 873-86. doi: 10.1016/j. neuron.2013.06.046.

79. Pickford F, Masliah E, Britschgi M, Lucin K, Narasimhan R, Jaeger PA, Small S, Spencer B, Rockenstein E, Levine $\mathrm{B}$, Wyss-Coray T. The autophagy-related protein beclin 1 shows reduced expression in early Alzheimer disease and regulates amyloid beta accumulation in mice. J Clin Invest. 2008; 118: 2190-9. doi: 10.1172/JCI33585.

80. Cho DH, Jo YK, Hwang JJ, Lee YM, Roh SA, Kim JC. Caspase-mediated cleavage of ATG6/Beclin-1 links apoptosis to autophagy in HeLa cells. Cancer Lett. 2009; 274: 95-100. doi: 10.1016/j.canlet.2008.09.004.

81. Lee CC, Huang CC, Hsu KS. Insulin promotes dendritic spine and synapse formation by the PI3K/Akt/mTOR and Rac1 signaling pathways. Neuropharmacology. 2011; 61: 867-79. doi: 10.1016/j.neuropharm.2011.06.003.

82. Li N, Lee B, Liu RJ, Banasr M, Dwyer JM, Iwata M, Li XY, Aghajanian G, Duman RS. mTOR-dependent synapse formation underlies the rapid antidepressant effects of NMDA antagonists. Science. 2010; 329: 959-64. doi: 10.1126/science. 1190287.

83. Bettio LE, Cunha MP, Budni J, Pazini FL, Oliveira A, Colla AR, Rodrigues AL. Guanosine produces an antidepressantlike effect through the modulation of NMDA receptors, nitric oxide-cGMP and PI3K/mTOR pathways. Behav Brain Res. 2012; 234: 137-48. doi: 10.1016/j.bbr.2012.06.021.

84. Burket JA, Benson AD, Tang AH, Deutsch SI. NMDA receptor activation regulates sociability by its effect on mTOR signaling activity. Prog Neuropsychopharmacol Biol Psychiatry. 2015; 60: 60-5. doi: 10.1016/j. pnpbp.2015.02.009.

85. Huang Y, Kang BN, Tian J, Liu Y, Luo HR, Hester L, Snyder SH. The cationic amino acid transporters CAT1 and CAT3 mediate NMDA receptor activationdependent changes in elaboration of neuronal processes via the mammalian target of rapamycin mTOR pathway. J Neurosci. 2007; 27: 449-58. doi: 10.1523/ JNEUROSCI.4489-06.2007.

86. Tang J, Xue W, Xia B, Ren L, Tao W, Chen C, Zhang H, Wu R, Wang Q, Wu H, Duan J, Chen G. Involvement of normalized NMDA receptor and mTOR-related signaling in rapid antidepressant effects of Yueju and ketamine on 
chronically stressed mice. Sci Rep. 2015; 5: 13573. doi: 10.1038/srep13573.

87. Wang Y, Wang W, Li D, Li M, Wang P, Wen J, Liang $\mathrm{M}$, Su B, Yin Y. IGF-1 alleviates NMDA-induced excitotoxicity in cultured hippocampal neurons against autophagy via the NR2B/PI3K-AKT-mTOR pathway. J Cell Physiol. 2014; 229: 1618-29. doi: 10.1002/jcp.24607.

88. Dai L, Zhuang L, Zhang B, Wang F, Chen X, Xia C, Zhang B. DAG/PKCdelta and IP3/Ca(2+)/CaMK IIbeta Operate in Parallel to Each Other in PLCgamma1Driven Cell Proliferation and Migration of Human Gastric Adenocarcinoma Cells, through Akt/mTOR/S6 Pathway. Int J Mol Sci. 2015; 16: 28510-22. doi: 10.3390/ ijms161226116.

89. Nicolini C, Fahnestock M. Decreased mTOR signaling via $\mathrm{p} 70 \mathrm{~S} 6 \mathrm{~K} / \mathrm{eIF} 4 \mathrm{~B}$ is associated with loss of the excitatory postsynaptic marker PSD-95 in autism. Int J Dev Neurosci. 2015; 47: 32. doi: 10.1016/j.ijdevneu.2015.04.093.

90. Giovannini MG, Lana D, Pepeu G. The integrated role of ACh, ERK and mTOR in the mechanisms of hippocampal inhibitory avoidance memory. Neurobiol Learn Mem. 2015; 119: 18-33. doi: 10.1016/j.nlm.2014.12.014.

91. Pedicord VA, Cross JR, Montalvo-Ortiz W, Miller ML, Allison JP. Friends not foes: CTLA-4 blockade and mTOR inhibition cooperate during $\mathrm{CD} 8+\mathrm{T}$ cell priming to promote memory formation and metabolic readiness. J Immunol. 2015; 194: 2089-98. doi: 10.4049/jimmunol.1402390.

92. Setoguchi R, Matsui Y, Mouri K. mTOR signaling promotes a robust and continuous production of IFN-gamma by human memory CD8+ T cells and their proliferation. Eur J Immunol. 2015; 45: 893-902. doi: 10.1002/eji.201445086.

93. Sowell RT, Marzo AL. Resident-Memory CD8 T Cells and mTOR: Generation, Protection, and Clinical Importance. Front Immunol. 2015; 6: 38. doi: 10.3389/ fimmu.2015.00038.

94. Su ZW, Liao JY, Zhang H, Zhang T, Wu F, Tian XH, Zhang FT, Sun WW, Cui QL. Postnatal high-protein diet improves learning and memory in premature rats via activation of mTOR signaling. Brain Res. 2015; 1611: 1-7. doi: 10.1016/j.brainres.2015.01.052.

95. Xiong H, Casse F, Zhou Y, Zhou M, Xiong ZQ, Joels M, Martin S, Krugers HJ. mTOR is essential for corticosteroid effects on hippocampal AMPA receptor function and fear memory. Learn Mem. 2015; 22: 577-83. doi: 10.1101/ $\operatorname{lm} .039420 .115$.

96. C ON. PI3-kinase/Akt/mTOR signaling: impaired on/ off switches in aging, cognitive decline and Alzheimer's disease. Exp Gerontol. 2013; 48: 647-53. doi: 10.1016/j. exger.2013.02.025.

97. Caccamo A, Magri A, Medina DX, Wisely EV, LopezAranda MF, Silva AJ, Oddo S. mTOR regulates tau phosphorylation and degradation: implications for Alzheimer's disease and other tauopathies. Aging Cell.
2013; 12: 370-80. doi: 10.1111/acel.12057.

98. Cai Z, Chen G, He W, Xiao M, Yan LJ. Activation of mTOR: a culprit of Alzheimer's disease? Neuropsychiatr Dis Treat. 2015; 11: 1015-30. doi: 10.2147/NDT.S75717.

99. Chano T, Okabe H, Hulette CM. RB1CC1 insufficiency causes neuronal atrophy through mTOR signaling alteration and involved in the pathology of Alzheimer's diseases. Brain Res. 2007; 1168: 97-105. doi: 10.1016/j. brainres.2007.06.075.

100. Fant X, Durieu E, Chicanne G, Payrastre B, Sbrissa D, Shisheva A, Limanton E, Carreaux F, Bazureau JP, Meijer L. cdc-like/dual-specificity tyrosine phosphorylationregulated kinases inhibitor leucettine L41 induces mTORdependent autophagy: implication for Alzheimer's disease. Mol Pharmacol. 2014; 85: 441-50. doi: 10.1124/ mol.113.090837.

101. Galvan V, Hart MJ. Vascular mTOR-dependent mechanisms linking the control of aging to Alzheimer's disease. Biochim Biophys Acta. 2015. doi: 10.1016/j. bbadis.2015.11.010.

102. Gouras GK. mTOR: at the crossroads of aging, chaperones, and Alzheimer's disease. J Neurochem. 2013; 124: 747-8. doi: 10.1111/jnc.12098.

103. Lafay-Chebassier C, Paccalin M, Page G, Barc-Pain S, Perault-Pochat MC, Gil R, Pradier L, Hugon J. mTOR/ p70S6k signalling alteration by Abeta exposure as well as in APP-PS1 transgenic models and in patients with Alzheimer's disease. J Neurochem. 2005; 94: 215-25. doi: 10.1111/j.1471-4159.2005.03187.x.

104. Li X, Alafuzoff I, Soininen H, Winblad B, Pei JJ. Levels of mTOR and its downstream targets 4E-BP1, eEF2, and eEF2 kinase in relationships with tau in Alzheimer's disease brain. FEBS J. 2005; 272: 4211-20. doi: 10.1111/j.17424658.2005.04833.x.

105. Liu H, Qiu H, Xiao Q, Le W. Chronic Hypoxia-Induced Autophagy Aggravates the Neuropathology of Alzheimer's Disease through AMPK-mTOR Signaling in the APPSwe/ PS1dE9 Mouse Model. J Alzheimers Dis. 2015; 48: 101932. doi: 10.3233/JAD-150303.

106. Ma T, Hoeffer CA, Capetillo-Zarate E, Yu F, Wong H, Lin MT, Tampellini D, Klann E, Blitzer RD, Gouras GK. Dysregulation of the mTOR pathway mediates impairment of synaptic plasticity in a mouse model of Alzheimer's disease. PLoS One. 2010; 5. doi: 10.1371/journal. pone. 0012845 .

107. Ma Y, Wu D, Zhang W, Liu J, Chen S, Hua B. Investigation of $\mathrm{PI} 3 \mathrm{~K} / \mathrm{PKB} / \mathrm{mTOR} / \mathrm{S} 6 \mathrm{~K} 1$ signaling pathway in relationship of type 2 diabetes and Alzheimer's disease. Int J Clin Exp Med. 2015; 8: 18581-90. doi:

108. Ma YQ, Wu DK, Liu JK. mTOR and tau phosphorylated proteins in the hippocampal tissue of rats with type 2 diabetes and Alzheimer's disease. Mol Med Rep. 2013; 7: 623-7. doi: 10.3892/mmr.2012.1186. 
109. Paccalin M, Pain-Barc S, Pluchon C, Paul C, Besson MN, Carret-Rebillat AS, Rioux-Bilan A, Gil R, Hugon J. Activated mTOR and PKR kinases in lymphocytes correlate with memory and cognitive decline in Alzheimer's disease. Dement Geriatr Cogn Disord. 2006; 22: 320-6. doi: $10.1159 / 000095562$.

110. Pei JJ, Hugon J. mTOR-dependent signalling in Alzheimer's disease. J Cell Mol Med. 2008; 12: 2525-32. doi: 10.1111/j.1582-4934.2008.00509.x.

111. Spilman P, Podlutskaya N, Hart MJ, Debnath J, Gorostiza O, Bredesen D, Richardson A, Strong R, Galvan V. Inhibition of mTOR by rapamycin abolishes cognitive deficits and reduces amyloid-beta levels in a mouse model of Alzheimer's disease. PLoS One. 2010; 5: e9979. doi: 10.1371/journal.pone.0009979.

112. Sun YX, Ji X, Mao X, Xie L, Jia J, Galvan V, Greenberg DA, Jin K. Differential activation of mTOR complex 1 signaling in human brain with mild to severe Alzheimer's disease. J Alzheimers Dis. 2014; 38: 437-44. doi: 10.3233/ JAD-131124.

113. Tang Z, Ioja E, Bereczki E, Hultenby K, Li C, Guan Z, Winblad B, Pei JJ. mTor mediates tau localization and secretion: Implication for Alzheimer's disease. Biochim Biophys Acta. 2015; 1853: 1646-57. doi: 10.1016/j. bbamcr.2015.03.003.

114. Wang C, Yu JT, Miao D, Wu ZC, Tan MS, Tan L. Targeting the mTOR signaling network for Alzheimer's disease therapy. Mol Neurobiol. 2014; 49: 120-35. doi: 10.1007/s12035-013-8505-8.

115. Wang S, Wu J, Nie SD, Bereczki E, Pei JJ. Dysregulated mTOR-dependent signaling in neurodegeneration or carcinogenesis: implication for Alzheimer's disease and brain tumors. J Alzheimers Dis. 2013; 37: 495-505. doi: 10.3233/JAD-130641.

116. Yates SC, Zafar A, Hubbard P, Nagy S, Durant S, Bicknell R, Wilcock G, Christie S, Esiri MM, Smith AD, Nagy Z. Dysfunction of the mTOR pathway is a risk factor for Alzheimer's disease. Acta Neuropathol Commun. 2013; 1: 3. doi: 10.1186/2051-5960-1-3.
117. Natunen T, Takalo M, Kemppainen S, Leskela S, Marttinen M, Kurkinen KM, Pursiheimo JP, Sarajarvi T, Viswanathan J, Gabbouj S, Solje E, Tahvanainen E, Pirttimaki T, et al. Relationship between ubiquilin-1 and BACE1 in human Alzheimer's disease and APdE9 transgenic mouse brain and cell-based models. Neurobiol Dis. 2016; 85: 187-205. doi: 10.1016/j.nbd.2015.11.005.

118. Lichtenthaler FW. 2-Oxoglycosyl ("ulosyl") and 2-oximinoglycosyl bromides: versatile donors for the expedient assembly of oligosaccharides with beta-Dmannose, beta-L-rhamnose, N-acetyl-beta-D-mannosamine, and N-acetyl-beta-D-mannosaminuronic acid units. Chem Rev. 2011; 111: 5569-609. doi: 10.1021/cr100444b.

119. Lichtenthaler SF. alpha-secretase in Alzheimer's disease: molecular identity, regulation and therapeutic potential. J Neurochem. 2011; 116: 10-21. doi: 10.1111/j.14714159.2010.07081.x.

120. Moss ML, Powell G, Miller MA, Edwards L, Qi B, Sang QX, De Strooper B, Tesseur I, Lichtenthaler SF, Taverna M, Zhong JL, Dingwall C, Ferdous T, et al. ADAM9 inhibition increases membrane activity of ADAM10 and controls alpha-secretase processing of amyloid precursor protein. J Biol Chem. 2011; 286: 40443-51. doi: 10.1074/ jbc.M111.280495.

121. Vincent B, Govitrapong P. Activation of the alpha-Secretase Processing of A beta PP as a Therapeutic Approach in Alzheimer's Disease. Journal of Alzheimers Disease. 2011; 24: 75-94. doi: 10.3233/Jad-2011-110218.

122. Grant RS, Naif H, Espinosa M, Kapoor V. IDO induction in IFN-gamma activated astroglia: a role in improving cell viability during oxidative stress. Redox Rep. 2000; 5: 1014. doi: 10.1179/135100000101535357. 